\title{
Farmers' Attitude Towards Ponds and Creeks Use in Some Selected Hilly Areas of Bangladesh
}

\author{
Prabin Chakma, Shaikh Shamim Hasan, S. M. Rafiquzzaman, and Md. Jahangir Alam
}

\section{ABSTRACT}

This study explores the status and potential of creek and pond as well as the attitude of the farmers towards pond and creek use. Following random sampling technique, a total of 60 fish farmers were sampled from Panchari Upazila, Khagrachari district of Bangladesh who were involved with pond and/or creek culture and they were interviewed through a predesigned questionnaire. The findings of the study indicated that most of the respondents belonged to above 50 years of age while $95 \%$ of them had small to medium (2-7 members) family size and about $72 \%$ of whom were literate either from primary to more than SSC level. Out of all the farmers, $85 \%$ of them had their own pond/creek and only $25 \%$ of them maintained communication with the fisheries related personnel (SUFO/UFO/others) to receive fish extension related information although, $36.7 \%$ of them didn't receive any training on agriculture and aquaculture related issues. By producing different types of fishes, they earned an average BDT 35915.25 from aquaculture which helped them maintaining positive attitude towards ponds and creeks use. The respondents of the study area perceived that ponds/creeks fish culture helped to increase their family income in the hilly areas and also uplifted their self-employment. Out of all the farmers, $65 \%$ had moderately to highly favorable attitude towards ponds and creeks use. Linear regression analysis indicated that age, level of education, income from aquaculture, agricultural training received, and aquaculture training received of the farmers had significant contribution on their attitude. The respondents of the study area perceived that ponds/creeks fish culture helped to increase family income in the hilly areas and also uplifted their self-employment.

Keywords: Farmers' attitude, ponds and creek use, hilly area, Bangladesh.

Submitted : August 06, 2021
Published : September **, 2021
ISSN: 2684-1827
DoI: 10.24018/ejfood.2021.3.5.349
Prabin Chakma
Ex MS Student, Dept. of Fisheries Biology
and Aquatic Environment, Bangabandhu
Sheikh Mujibur Rahman Agricultural
University (BSMRAU), Gazipur-1706,
Bangladesh. and
Master Trainer, Agriculture and Food
Security Project - III, Bandarban Hill
District Council (BHDC), Technical
Support by UNDP, Bangladesh.
(e-mail: prabinchakma25@gmail.com)
Shaikh Shamim Hasan*
Dept. of Agricultural Extension and Rural
Development, Bangabandhu Sheikh
Mujibur Rahman Agricultural University
(BSMRAU), Gazipur-1706, Bangladesh.
(e-mail: shamim.aer@bsmrau.edu.bd)
S. M. Rafiquzzaman
Professor, Dept. of Fisheries Biology and
Aquatic Environment, Bangabandhu
Sheikh Mujibur Rahman Agricultural
University (BSMRAU), Gazipur-1706,
Bangladesh.
(e-mail: rafiquzzaman@ ${ }^{\circ}$ bsmrau.edu.bd)
Md. Jahangir Alam
Professor, Dept. of Fisheries Biology and
Aquatic Environment, Bangabandhu
Sheikh Mujibur Rahman Agricultural
University (BSMRAU), Gazipur-1706,
Bangladesh.
(e-mail: mjalam.bsmrau@gmail.com)
*Corresponding Author

Published : September **, 202

2684-1827

Prabin Chakma

MS Student, Dept. of Fisheries Biology Sheikh Mujibur Rahman University (BSMRAU), Gazipur-1706, angladesh. and

Security Project - III, Bandarban Hill District Council (BHDC), Technical

Shaikh Shamim Hasan

Dept. of Agricultural Extension and Rural Mujibur Rahman Agricultural University BSMRAU), Gazipur-1706, Bangladesh.

bsmrau.edu.bd)

Professor, Dept. of Fisheries Biology and Aquatic Environment, Bangabandhu University (BSMRAU), Gazipur-1706, Bangladesh.

Md. Jahangir Alam

Professor, Dept. of Fisherie Sheikh Mujibur Rahman Agricultura University (BSMRAU), Gazipur-1706, Bangladesh.

*Corresponding Author

\section{INTRODUCTION}

The Chittagong Hill Tracts (CHT) are located in Bangladesh's hilly region. The Chittagong Hill Tracts, in Bangladesh's southeastern region, are the country's sole large hilly territory. Bandarban, Rangamati, and Khagrachhari are the three hill districts that make up the CHT. The Chittagong Hill Tracts cover roughly $13,2945 \mathrm{~km} 2$, or nearly one-tenth of Bangladesh's total land area [1]. The creek refers to the hilly slopes that are connected to the main lake or its stream and become swamped with massive hilly streams during the monsoon [2].

Fish farming in the three hill districts' waterways has a strong chance of generating a variety of fish species. The arms of the creek should be encircled by steep ground on three sides, while the rest should remain connected to the lake's main body. In the CHT, there are a total of 4727 creeks (covering 4297 acres), 1200 of which are near to the Kaptai Lake. The production capacity of these creeks is $2100 \mathrm{~kg} / \mathrm{ha}$ that is eight to nine times more than the Kaptai Lake [3]. As a consequence of Bangladesh Fisheries Development Corporation (BFDC) records, in the year 2002-03 total fish production of the Kaptai Lake was 4556 MT but it was 9364 MT in the year 2015-16. The total fish production from this lake has gotten a lot of attention in the last fifteen years, but it was clear that the production of major carp species (Labeo rohita, Catla catla, Cirrhinus cirrhosus) has decreased dramatically, whereas small fish species (Gudusia chapra and Corica soborna) has increased rapidly [4].

Despite the fact that the lake is stocked with a large number of carp fingerlings each year, the aforementioned species is declining at an alarming rate. According to a study conducted 
by [5], lake production has decreased due to a lack of optimal water flow, siltation, which limits the rate of water flow and causes habitat degradation, the loss of spawning grounds, and a fall in natural seed production of key carp fishes. Meanwhile, existing fish output at these lakes is declining, necessitating a substantial management effort through creek aquaculture to fully exploit the lake's fishing potential. Chittagong Hill Tracts yearly fish production is 14773.46 MT (culture, capture, and Kaptai Lake), which is a small percentage of overall annual inland catch [6]. Due to a shortage of water, "aquaculture" is not very popular in Khagrachari. Aquaculture could be extended in hilly areas by establishing artificial water bodies, primarily creeks. The government of Bangladesh encouraged aquaculture in the hill areas' creeks, ponds, and lakes in the mid-1990s. By modifying creek flows and constructing tiny dams as part of the "Fish Culture Development (in Hill) and Extension" project, 11.5 ha of nursery ponds and 92 ha of other water bodies were developed and placed under fish culture [7]. The annual total fish production of the CHT is 15443 MT (culture, capture and Kaptai Lake) in which in Khagrachhari the fish production is $3038 \mathrm{MT}$ [8]. The Department of Fisheries is attempting to modernize stream aquaculture activities in the hill areas, as well as rehabilitate creeks by mending them and taking steps to construct new creeks for fish culture.

Though the fish availability of the hill tracts area is declining day by day as the cultivable pond and creek is decreasing for population explosion. Some natural as well as anthropogenic activities are responsible for this. Furthermore, the Bangladeshi government has developed major policy thrust areas such as maximizing the utilization of accessible resources, capturing and reversing degraded lands [9], which includes hilly creeks and ponds. Moreover, most of the fishermen are poor and they are deprived of many opportunities. It is necessary to judge the attitude of the fish farmers so that they can take initiative for more production of fishes by proper utilization of limited resources such as creek and pond. Although, there is a dearth of research on the farmers' attitude towards ponds and creek use. Hence, we conducted the current study in the Panchari upazila (lower administrative unit) of Khagrachari district in Bangladesh for examining the fish farmers attitude towards ponds and creeks use. We also measured how different socioeconomic factors of the farmers could influence their attitude.

\section{METHODOLOGY}

\section{A. Research Design and Sample}

This study was conducted using descriptive survey research. The study's main goals were to observe farmers' attitude on pond and creek use, as well as to learn about the socio-demographic factors that influenced their attitudes. We used an interview schedule to conduct face-to-face interviews with farmers in order to acquire relevant data for the research. We did the study in Panchari, a Bangladeshi upazila in the Khagrachari area. To collect the data, we identified five unions within the same upazila. Logang, Chengi, Panchari, Lotiban, and Ultachari were the unions. These regions were chosen specifically because there were a large number of pond and creek farmers (a total of 148) in the area. A total of
60 farmers (about 41\%) were chosen as samples from the 148 farmers (population) using a random selection technique. Another 07 respondents were kept in reserve list to fill up the gap if any of the original samples would absent during the data collection.

\section{B. Selection of Variables and Their Measurement Technique}

Based on the assessment of some previous studies [10][14], we identified eight variables as independent variables of this study. The variables were the farmers age, family size level of education, family annual income, income from aquaculture, extension media contact, training received on agriculture, training received on aquaculture.

\section{Measurement Technique of the Independent Variables}

We calculated the respondents' age by subtracting the time since their birth from the date of the interview and assigning a score of one (1) to each year of age. While we defined educational qualification as a respondent's formal education, we provided a score of one (1) for each year the respondent passed any formal educational institution. Additionally, those who could not read or write, or who had no formal education, were given a score of zero $(0)$.

Ownership of ponds and creeks of the respondents was calculated by asking them whether they had ponds and creeks by their own, others (as lease) and both and suitable scoring were provided. We calculated family size by assigning a score of one (1) to each family member who shared a home and ate meals together. We also calculated extension media communication by assigning different scores to different extension communication sources by the respondents, such as communication with Sub Assistant Upazila Fisheries Officer (SUFO), contact with Upazila Fisheries Officer (UFO), and contact with other fisheries-related NGO officers. We calculated the respondents' family yearly income based on their total earnings from several sources in 2019, such as agricultural, business, service, and other, all of which were stated in BDT (Bangladeshi Taka). Meanwhile, aquaculture income was calculated using the respondents' earnings from selling fish to consumers and was expressed in BDT. We calculated the respondents' agricultural and aquaculture training by assigning a score of one (1) for each day of agriculture and aquaculture related training received by a respondent from various organizations.

\section{Measurement Technique of the Dependent Variable}

The farmers' attitudes on pond and creek use were identified as the study's dependent variable. We set a total of ten statements to recognize this issue, and the respondents were requested to answer to those attitude statements, which were arranged randomly.

To calculate the level of agreement, we took a five-point Likert-type scale as, strongly agree (5), agree (4), undecided (3), disagree (2) and strongly disagree (1) for positive statements and negative statements received reversal scoring. Other studies [9], [10], [15]-[17], used the same type of measurement technique. We, then, calculated the respondents' attitude score towards ponds and creeks use by constructing ponds and creeks use attitude index (PCAI). We followed a twos step procedure to construct the PCAI utilizing the (1): 
$\mathrm{PCAI}=\sum_{j=1}^{10}, \sum_{m=0}^{5}, \sum_{q=0}^{1} E_{j} R_{m} W_{q}$

The sample respondents were given a total of 10 ponds and creek use statements to read and were asked for their opinions (Ej). The following ten statements were chosen after extensive discussion and pre-testing of the interview schedule. Then, for each recognized perception, we assigned a value of 01 , and if not, a value of 0 . In the second phase, we asked the respondents to express their views on a five-point scale $(\mathrm{Rm})$, with a score of 05 for each strongly agreeing opinion and 1 for each strongly disagreeing opinion. Then we turned the rankings into a weighted score $(\mathrm{Wg})$. After that, we assigned 02 to the lowest rank of 01 , and 01 to the highest rank of 05 . The PCAI for each respondent was derived by adding the weighted scores together. [12] for example, used this approach and equation.

\section{E. Multiple Linear Regression Procedure}

We used full-model regression analysis on eight independent variables (respondents age, family size, level of education, family annual income, income from aquaculture, extension media contact, training received on agriculture, and training received on aquaculture) to determine the factors influencing respondents' attitudes towards ponds and creeks use. Due to the nature of the dependent variable, we then performed the linear regression model. Hence, we used the latent equation (2):

$$
y=\beta_{o}+\beta_{1} x_{1}+\beta_{2} x_{2}+\ldots \ldots \ldots \ldots+\beta_{8} x_{8}+\varepsilon
$$

where, y was the dependent variable, $\beta_{0}$ was the intercept, $\beta_{1}$. 8 Was the coefficient, and $x_{1-8}$ was the independent variables.

The independent variables that influenced the respondents' attitude towards ponds and creek use were as follows:

$\mathrm{X}_{1}=$ Age of the respondents in years;

$\mathrm{X}_{2}=$ Family size of the respondents in numbers;

$\mathrm{X}_{3}=$ Level of education of the respondents in years;

$\mathrm{X}_{4}=$ Ownership of ponds and creeks;

$\mathrm{X}_{5}=$ Family annual income of the respondents in BDT;

$\mathrm{X}_{6}=$ Income from aquaculture;

$\mathrm{X}_{7}=$ Extension media communication;

$\mathrm{X}_{8}=$ Respondents agricultural training received;

$\mathrm{X}_{9}=$ Respondents aquaculture training received.

In addition, we used multiple regression analysis with significance levels of 0.10 , and 0.05 to estimate the impact of the attributes.

\section{RESULTS AND DISCUSSION}

According to the data in Table I, 53.30\% of the respondents were between the ages of 31 and 50, while 41.7 $\%$ were over the age of 50, with an average age of around 50 years. When [18] conducted a study on the fisherman of the old Brahmaputra River, they came up with identical results. [13] discovered that young people had more social contact and were more likely to have a broader perspective than elderly persons. According to Table I, the number of family members of the respondents ranged from 2 to 11 in the study region, and the average number of persons per household was 4.72, which is slightly higher than the CHT average and also higher than the national average of 4.2 [4]. [19] in Nigeria found that having a large family means having more mouths to feed, which necessitates increased exploitation of various resources and services. The respondents' educational levels varied from 0 to 12 . Around 81.70 percent of those polled had had education ranging from primary to post-secondary education. The average educational level was 6.90. When [16] did their study with pineapple growers in Bangladesh's Tangail area, they discovered a comparable average level of schooling. Moreover, the level of educational status of the study area proved a good picture of improvement of the education sector of the country, Bangladesh. The study area is situated in the remote corner of the country with faulty transportation system. As this is a hilly area of the country, hence, the overall education situation and facility was not the same as the other parts of the country.

We also noticed who owned the ponds and creeks in the research region, and we divided the respondents into three groups based on this. The data in this table showed that the majority of the respondents in the research region $(85 \%)$ had their own ponds and creeks that they used for fish culture. On the other hand, $13.3 \%$ of respondents did not have access to a creek or pond, so they practiced fish farming in the creeks or ponds of others (as lease). The ownership of ponds and creeks are greater determinant of fish production in the remote hilly areas of the country. Because, forests provide a sustainable supply of life, such as water and oxygen, as well as acting as a carbon sink in the fight against global warming and climate change [1]. Furthermore, Bangladesh's government has placed a greater emphasis on closed-water fisheries production. Despite the fact that siltation and drying of perennial water bodies have steadily diminished fish habitat in rivers, creeks, and canals [20]. A small-holder aquaculture strategy was also proposed by the government to accommodate landless and marginal farmers.

According to the findings in Table I, the majority of respondents $(75 \%)$ had no interaction with any of the extension media in order to obtain extension services. At the same time, the remaining $25 \%$ of respondents kept in touch with SUFOs (Senior Upazila Fisheries Officers), UFOs (Upazila Fisheries Officers), and other fisheries-related nongovernmental organizations. Extension media communication refers to one's interaction with a variety of knowledge and information sources. This causes users to have a cognitive shift, which leads to changes in attitude, behavior, and skill [17]. However, due to the research area's remote location and defective transportation system, extension professionals were unable to visit the study region on a regular basis and give various sorts of extension services to the farmers.

The respondents' average annual income in the research region was BDT 102933, which was lower than Bangladesh's national average annual income of BDT 159096 in rural areas [21]. The majority of the interviewees at the research site worked as farmers and had low-income. They didn't have much of a chance to change careers. Furthermore, the research area was in Bangladesh's isolated highland regions. As a result, their annual revenue was significantly reduced. According to Table I, the majority of the respondents $(79.7 \%)$ earned less than BDT 50000 per year (2019) from aquaculture. It was followed by approximately $17 \%$ of them in the BDT 50001 to 100000 category. Meanwhile, 
respondents in the research area had an average aquaculture income of BDT 35915. According to [22], majority of respondents earned around BDT 33000 from fishing. The majority of respondents $(45 \%)$ received one to two training on various agricultural topics, while 56.7 percent received one to three hours of instruction on aquaculture. However, 36.7 percent of respondents said they had never received any training on agricultural or aquaculture matters.

\begin{tabular}{|c|c|c|c|c|}
\hline Characteristics & Categories & Respondents (\%) & Observed score & Mean \\
\hline \multirow{4}{*}{ Age } & $<30$ years & 5.0 & $28-60$ years & 49.73 \\
\hline & $31-40$ years & 25.0 & & \\
\hline & $41-50$ years & 28.3 & & \\
\hline & $>50$ years & 41.7 & & \\
\hline \multirow[b]{2}{*}{ Family size } & Small (2 to 4$)$ & 45.0 & $2-11$ & 1.62 \\
\hline & Medium (5 to 7 ) & 50 & & \\
\hline \multirow{4}{*}{ Level of Educational } & Illiterate & 18.3 & $0-12$ & 6.90 \\
\hline & $1-5$ & 23.3 & & \\
\hline & $6-10$ & 26.7 & & \\
\hline & $>10$ & 31.7 & & \\
\hline \multirow{3}{*}{$\begin{array}{l}\text { Ownership of ponds and } \\
\text { creeks }\end{array}$} & Personal pond/creek & 85.0 & -- & -- \\
\hline & Lease of pond/creek & 13.3 & & \\
\hline & Mixed pond/creek & 1.7 & & \\
\hline \multirow{3}{*}{$\begin{array}{l}\text { Extension Communication } \\
\text { sources }\end{array}$} & Communication with SUFO & 8.3 & & \\
\hline & Communication with UFO & 10 & & \\
\hline & Communication with others & 6.7 & & \\
\hline \multirow{3}{*}{ Family annual income } & Income within BDT 100000 & 65.0 & BDT 10000- & 102933.33 \\
\hline & Income BDT 100000 to 200000 & 26.7 & 500000 & \\
\hline & Income more than BDT 200000 & 8.3 & & \\
\hline \multirow{3}{*}{$\begin{array}{c}\text { Agriculture Training } \\
\text { received }\end{array}$} & No training & 36.7 & $0-3$ & 1.15 \\
\hline & 1 to 2 training & 45.0 & & \\
\hline & More than 2 training & 18.3 & & \\
\hline \multirow{3}{*}{ Aquaculture training received } & No training & 36.7 & $0-4$ & 1.14 \\
\hline & 1 to 3 training & 56.7 & & \\
\hline & More than 3 training & 6.6 & & \\
\hline \multirow[b]{2}{*}{ Aquaculture income } & Income within BDT 50000 & 79.7 & BDT 0-160000 & 35915.25 \\
\hline & Income BDT 50001 to 100000 & 16.9 & & \\
\hline
\end{tabular}

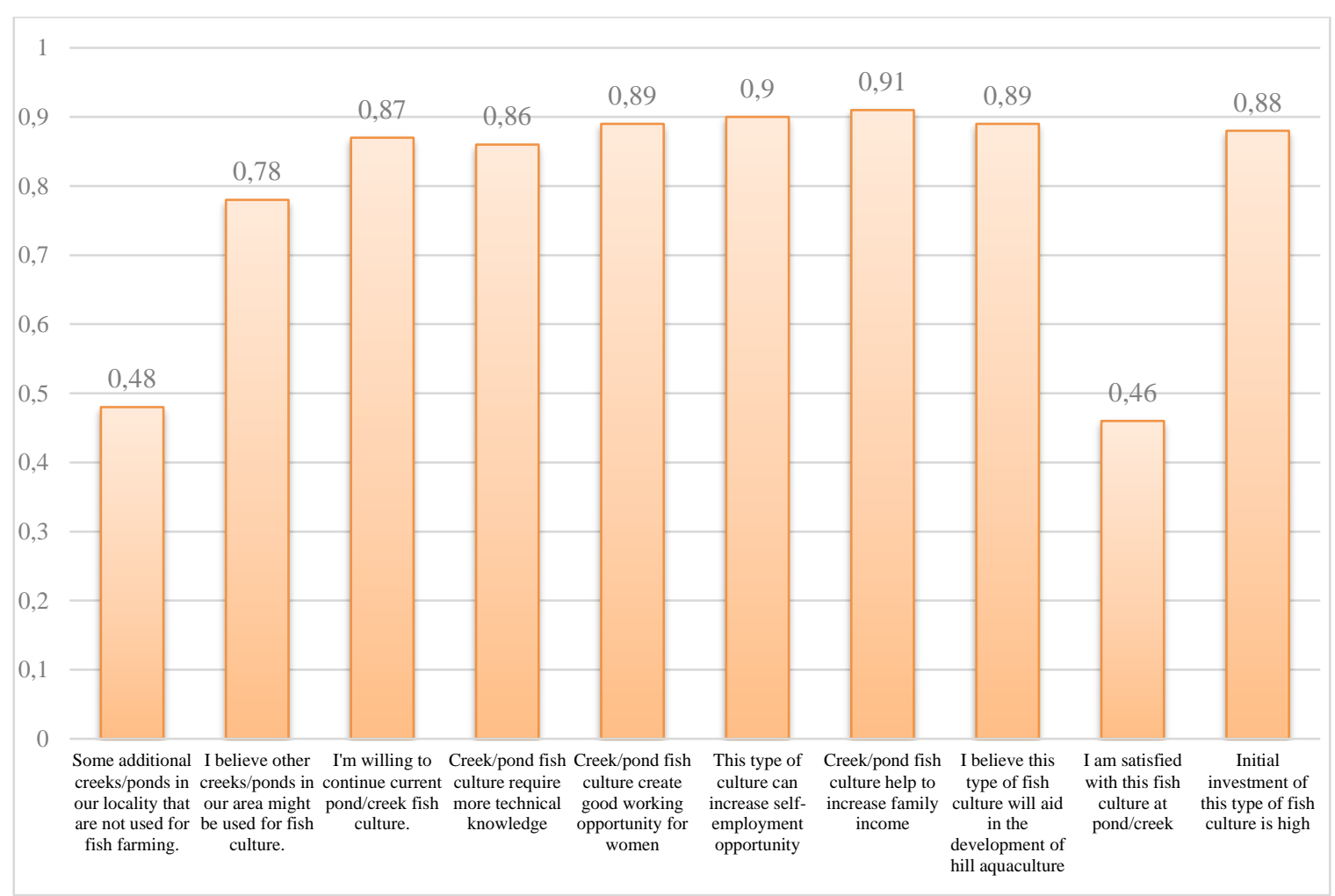

Fig. 1. Rank order of the statements according to respondents' attitude index. 


\section{A. Respondents Attitude Index of Ponds and Creeks Use}

We observed the data furnished in Fig. 1 that the respondents had topmost attitude towards ponds and creeks use in respect of 'Creek/pond fish culture help to increase family income' with the highest (mean $=0.91$ ) followed by 'This type of culture can increase self-employment opportunity' (mean $=0.90$ ). Accordingly, 'Creek/pond fish culture create good working opportunity for women' (mean= 0.89 ) ranked $3^{\text {rd }}$. It was revealed from the top ranked statements that the respondents were agreed with the positive aspects of utilizing ponds and creeks in the hilly areas of Bangladesh. According to Table I, it was exposed that on an average the respondents earned about BDT 35915 from aquaculture in a year. The respondents of the study area cultured different types of fishes in the ponds and creeks, hence, this is a good tool to increase the family income of the respondents. Moreover, the respondents also opined that ponds and creeks fish culture provided them good selfemployment and women employment opportunity.

Small-scale aquaculture is a stepping stone to larger-scale aquaculture. It is easily embraced by resource-poor farmers due to its modest size and low risks. They can scale up their farming operations after learning the techniques if they find it to be cost-effective [23].

Moreover, Bangladesh has over a million fishponds, the most of which are owned by the poor and are referred to as fish factories. Bangladesh gets roughly 0.5 billion dollars from fish exports, with small-scale farmers benefiting directly. Fish farming, particularly prawn farming in rice fields, has proven to have the ability to raise their income by up to four times. Shrimp and prawn exports bring in roughly $\$ 400$ million each year to the economy [24]. Hence, there is huge potentiality of ponds and creek fish culture with respect to self-employment and women employment in the hilly areas of Bangladesh.

The respondent showed less favorable attitude to some statements as per their mean score, like 'I am satisfied with this fish culture at pond/creek' (mean $=2.3$ ) ranked $10^{\text {th }}$. Which means that the respondents of the study area were not satisfied at all on the production and earnings from the ponds and creeks. Findings obtained from the Table I exhibited that still $36.7 \%$ of the respondents didn't receive any training on aquaculture and $56.7 \%$ respondents received only 1 to 3 training on aquaculture. Which meant that the respondents had knowledge and skill gap to performing fish culture in the ponds and creeks of the hilly areas. Therefore, it is necessary to arrange training related to fish production for the respondents of the study area.

\section{B. Respondents' Overall Attitude towards Ponds and Creeks Use}

Meanwhile, we also calculated the overall attitude of the respondents towards ponds and creeks use. To do that we calculated the ponds and creeks use attitude index (PCAI) and classified the respondents into four categories as indicated in Fig. 2. The respondents' overall attitude scores toward pond and creek use ranged from 34 to 46.

Data contained in Fig. 2 exhibited that $65 \%$ of the respondents maintained moderately to highly favorable attitude towards ponds and creeks use change. Although 35\% respondents maintained less favorable attitude towards ponds and creeks use. Similar moderately favorable attitudes were also obtained by [25]. [26] also found that the highest proportion $(61.7 \%)$ of the respondents had highly favorable attitude towards the Community Managed Fisheries (CMF).

Bangladesh is mostly a rice and fish-eating country. Her primary source of animal protein is aquatic, primarily from fish and crabs. Since the 1960s, high yielding rice varieties have been pushed in response to rising population and increased demand for cereal-based diets. This has increased food grain output and rendered Bangladesh self-sufficient in carbohydrate-based diets, but it has also resulted in a significant decrease in wild fish production from open inland lakes due to irrigation, herbicides, and fertilizers [27].

Bangladeshi hill inhabitants generate a portion of their own food through shifting agriculture. They haven't fully started raising fish yet. Despite this, fish/seafood consumption per capita in the hill areas is lower than the rest of the country. Bangladesh's Department of Fisheries is attempting to upgrade and expand fish culture efforts in hill districts. In Kaptai Lake and highland creeks, the Bangladesh Fisheries Research Institute is attempting to develop cage and pen culture. The Institute is also working on developing low-cost cage culture feeds [27].Henceforth, moderately to highly favorable attitude of the respondents in the study area will helpful to use more and produce more from their ponds and creeks.

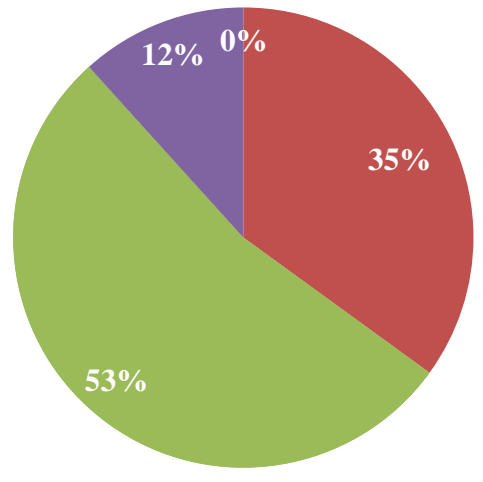

- No favorable attitude (up to 30)

- Less favorable attitude (31-38)

Moderately favorable attitude (39-42)

- Highly favorable attitude (> 42)

Fig. 2. Rank order of the statements according to respondents' attitude index.

\section{Attributes influencing respondents' attitude towards ponds and creek use}

To determine the attributes influencing the respondents' attitude towards ponds and creeks use, 10 independent variables were subjected to full-model regression analysis. In the full-model regression analysis, it was revealed that age, level of education, income from aquaculture, agricultural training received, and aquaculture training received of the respondents were found to have significant influence (Table II).

The model seems to have good fitness as indicated by Rsquare. The coefficient of multiple determination, $\mathrm{R}^{2}$ was 0.534 for the model. This means that the explanatory variables in the model explained $53.4 \%$ of the variation in respondents' attitude towards ponds and creeks use. The estimated result of the multiple regression analysis is satisfactory as it fulfils some of the criteria. Firstly, the adjusted $\mathrm{R}^{2}$ (which is the measure of goodness of fit of the 
estimated regression model) value of 0.443 indicates a good fitting of the model. The model also depicts that the F-test shows that the estimated regression is quite relevant which means dependent variable is related to each specified explanatory variable. The contributions of the selected factors on the respondents' attitude towards ponds and creek use are discussed below:

TABLE II: RESPONDENTS' SELECTED CHARACTERISTICS AND THEIR CONTRIBUTION TO ATTITUDE TOWARDS PONDS AND CREEK USE

\begin{tabular}{|c|c|c|c|c|c|}
\hline Sl. & $\begin{array}{l}\text { Characteristics of } \\
\text { the respondents }\end{array}$ & $\begin{array}{c}\text { Coefficient } \\
\beta\end{array}$ & SE & $\begin{array}{c}\mathrm{t}- \\
\text { value }\end{array}$ & $\begin{array}{c}p \\
\text { (significant) }\end{array}$ \\
\hline $\mathrm{X}_{1}$ & Age & $0.307 * *$ & 0.055 & 2.653 & 0.011 \\
\hline $\mathrm{X}_{2}$ & Family size & -0.149 & 0.405 & $\begin{array}{c}- \\
1.309\end{array}$ & 0.197 \\
\hline $\mathrm{X}_{3}$ & $\begin{array}{l}\text { Level of } \\
\text { education }\end{array}$ & $0.219^{*}$ & 0.146 & 1.840 & 0.072 \\
\hline $\mathrm{X}_{4}$ & $\begin{array}{l}\text { Ownership of } \\
\text { pond \& creek }\end{array}$ & 0.004 & 1.500 & 0.041 & 0.967 \\
\hline $\mathrm{X}_{5}$ & $\begin{array}{l}\text { Family annual } \\
\text { income }\end{array}$ & -0.091 & 0.002 & $\begin{array}{c}- \\
0.677\end{array}$ & 0.501 \\
\hline$X_{6}$ & $\begin{array}{l}\text { Income from } \\
\text { aquaculture }\end{array}$ & $0.301 * *$ & 0.001 & 2.323 & 0.024 \\
\hline $\mathrm{X}_{7}$ & $\begin{array}{l}\text { Extension media } \\
\text { communication }\end{array}$ & 0.028 & 0.761 & 0.227 & 0.821 \\
\hline $\mathrm{X}_{8}$ & $\begin{array}{c}\text { Agricultural } \\
\text { training received }\end{array}$ & $0.218^{*}$ & 0.618 & 1.811 & 0.076 \\
\hline $\mathrm{X}_{9}$ & $\begin{array}{c}\text { Aquaculture } \\
\text { training received }\end{array}$ & $0.280 * *$ & 0.464 & 2.403 & 0.020 \\
\hline
\end{tabular}

Note: $\mathrm{R}=0.665, \mathrm{R}^{2}=0.534$, Adjusted $\mathrm{R}^{2}=0.443$, Critical Value of $\mathrm{F}=$ 4.411 , and '**' \& '*' represent significant at $5 \%$ and $10 \%$ level of probability respectively

Data obtained through regression analysis in Table II exhibited that, respondents' age exhibited a significant and positive influence on the respondents' attitude towards ponds and creeks use. The value of regression coefficient was 0.307 which was significant at $5 \%$ level. Which implies that with the increase of age there will be increase of the attitude of the respondents towards ponds and creeks use. The regression coefficient exhibited that for every unit increase of age there was a corresponding 0.130 unit increase of attitude towards ponds and creek use. Similar type of positive and significant contribution of age was also observed by other researchers [28]-[30] in their respective research.

Alongside, we observed a positive and significant contribution of level of education of the respondents on their attitude towards ponds and creeks use as the value of regression coefficient was 0.219 which was significant at $10 \%$ level. The regression coefficient value $(\beta)$ told us that for one unit increase of education would be resulted 0.219 unit increase of attitude of the respondents towards ponds and creeks use. This means that if the education level of the respondents could be increased among the local fish farmers, then their attitude towards pond and creek use would positively increase. Through their respective researches different researchers, like, [10], [16], [30] also found similar type of positive and significant contribution.

Meanwhile, through this study, we detected a significant and positive influence of the respondents' income from aquaculture on their attitude towards ponds and creeks use. The regression coefficient ' $\beta=0.301$ (significant at $5 \%$ level)' indicated that the average value of attitude increased by 0.301 times for one unit increase of income from aquaculture. [17] reported a similar type of significant and positive contribution of family annual income on farmers' attitudes regarding using agrochemicals in rice fields. As a result of this study, we discovered that the respondents' agricultural training and aquaculture training had a significant and positive influence on their attitude toward ponds and creek use change, with the " $\beta$ value 0.218 and 0.280 " for agricultural training and aquaculture training, respectively. This indicates that if the farmers receive more training in both agriculture and aquaculture, their attitudes regarding the usage of ponds and creeks will be favorably influenced. Other investigations found a similar type of significant positive link between agricultural training obtained and attitude/perception [9], [10], [13], [31].

\section{CONCLUSIONS}

Findings of the study exhibited that most of the fish farmers of the study area belonged to above 50 years of age, with average family size of 4.72 person and $72 \%$ of them were literate. About $75 \%$ of the farmers didn't maintain any communication with any extension agent for receiving extension services and $36.7 \%$ of them were still outside of agriculture and aquaculture related training facilities. Although, 85\% respondents had their own ponds and creeks and by utilizing these they earned an average income of BDT 35915 from aquaculture which helped them maintaining positive attitude towards ponds and creeks use.

The fish farmers of the study area opined that hill aquaculture ensured their family income as well as increased self-employment. About $65 \%$ of the farmers had moderately to highly favorable attitude towards ponds and creeks uses. That means still $35 \%$ of them didn't have good attitude towards ponds and creeks use. Poor extension communication, lack of training facilities on aquaculture accelerated this attitude. Moreover, age, level of education, income from aquaculture, agricultural training received, and aquaculture training received of the farmers were the contributing factors that influenced their attitude towards ponds and creeks use. Therefore, it may be concluded that any attempt to increase these selected characteristics would be helpful for the improvement of the attitude of the farmers towards ponds and creeks use. The findings of the study will be useful for planning and execution of fisheries related technologies and fish related policy of Bangladesh.

Similar studies in other parts of the Chattogram Hill Tracts (CHT) could provide a more accurate picture of ponds and creeks aquaculture, as the current study was limited to the Panchari upazila of Khagrachari district. More training, extension, and awareness programs on stream fish should be organized for local farmers, and various government agencies (most notably the Department of Fisheries) and nongovernmental organizations (NGOs) can help. Furthermore, we only noticed the influence of nine socioeconomic characteristics of farmers on their attitudes regarding the utilization of ponds and creeks. Other independent and dependent variables can be incorporated into future research. 


\section{REFERENCES}

[1] S. S. Hasan, N. S. Sarmin and M. M. G., "Assessment of scenariobased land use changes in the Chittagong Hill Tracts of Bangladesh," Environmental Development, vol. 34, p. 100463, 2020.

[2] S. S. Basak, M. M. Rahman, M. A. Bashar, M. M. H. Khan and M. Y. Mahmud, "Production and Growth Performance under Carps Polycuture with Different Stocking Densities in Hilly Creeks of Kaptai Lake, Rangamati," MOJ Ecology \& Environmental Sciences, vol. 2, no. 4, p. 00029, 2017.

[3] M. Alamgir and S. U. Ahmed, "Fish culture techniques in creeks in Kaptai Lake using pens," Extension Manual, vol. 33, no. 16, 2005.

[4] BBS, Yearbook of Agricultural Statistics. Dhaka, Dhaka: Ministry of Planning, Government of the people's Republic of Bangladesh, 2018.

[5] M. A. Bashar, S. S. Basak, K. B. Uddin, A. S. Islam and Y. Mahmud, "Changing trends of physicochemical parameters in Kaptai Lake of Bangladesh," Research in Agriculture Livestock and Fisheries, vol. 2, no. 2, pp. 319-327, 2015.

[6] FRSS, Yearbook of Fisheries Statistics of Bangladesh. Bangladesh Bureau of Statistics, Dhaka: Planning Commission, Bangladesh., 2014.

[7] R. Arthur, W. Leschen and D. Little, Fisheries and aquaculture and their potential roles in development: an assessment of the current evidence, 2015.

[8] BBS, Statistical Yearbook of Bangladesh. Bangladesh Bureau of Statistics, Dhaka: Planning Commission, Bangladesh., 2019.

[9] S. S. Hasan, A. Mohammad, M. K. Ghosh and M. I. Khalil, "Assessing of farmers' opinion towards floating agriculture as a means of cleaner production: A case of Barisal district, Bangladesh.," Current Journal of Applied Science and Technology, vol. 20, no. 6, pp. 1-14, 2017.

[10] S. Saha, S. S. Hasan, M. E. Haque and T. Ahamed, "Perception Based Assessment of Ecosystem Services of Madhupur Sal Forest in Bangladesh," European Journal of Agriculture and Food Sciences, vol. 3, no. 1, pp. 39-44, 2021.

[11] M. K. Ghosh and S. S. Hasan, "Farmers' attitude towards sustainable agricultural practices.," Bangladesh Research Publications Journal, vol. 8, no. 4, pp. 227-235, 2013.

[12] S. S. Hasan, S. Roy, S. Saha and M. Z. Hoque, "Assessment of the Farmers' Perception on Vermicompost as Waste Management Practice and Economic Return in Some Areas of Bangladesh," European Journal of Agriculture and Food Sciences, vol. 3, no. 3, pp. 14-20, 2021.

[13] S. S. Hasan, M. Z. Turin, M. K. Ghosh and M. I. Khalil, "Assessing Agricultural Extension Professionals Opinion towards Sustainable Agriculture in Bangladesh," Asian Journal of Agricultural Extension, Economics and Sociology, vol. 17, no. 1, pp. 1-13, 2017.

[14] S. S. Hasan, M. K. Ghosh, M. S. Arefin and S. Sultana, "Farmers' Attitude Towards Using Agro-Chemicals in Rice Production: A Case in Laxmipur District of Bangladesh," The Agriculturists, vol. 13, no. 2, p. 105, 2015.

[15] N. Salawat, S. S. Hasan, A. S. Khan, M. S. Rahman, M. M. Hoque and M. Moonmoon, "Study on knowledge and attitude of mushroom growers at selected upazilas of Dhaka," Bangladesh Journal of Mushroom, vol. 7, no. 1, pp. 49-57, 2013.

[16] S. S. Hasan, M. A. Ali and M. I. Khalil, "Impact of pineapple cultivation on the increased income of pineapple growers," The Agriculturists, vol. 8, no. 2, pp. 50-56, 2010.

[17] S. S. Hasan, M. Hossain, S. Sultana and M. K. Ghosh, "Women's involvement in income generating activities and their opinion about its contribution: A study of Gazipur District, Bangladesh," Science Innovation, vol. 3, no. 6, pp. 72-80, 2015.

[18] K. R. Kabir, R. K. Adhikary, M. B. Hossain and M. H. Minar, "Livelihood status of fishermen of the old Brahmaputra River, Bangladesh.," World Applied Sciences Journal, vol. 16, no. 6, pp. 869873, 2012.

[19] M. F. Adekunle and B. M. Agbaje., "Public willingness to pay for ecosystem service functions of a peri-urban forest near Abeokuta, Ogun State, Nigeria," Journal of Development and Agricultural Economics, vol. 4, no. 2, pp. 45-50, 2012.

[20] Ministry of Planning, Prospective Plan of Bangladesh 2010-2021: Making Vision 2021 a reality., General Economics Division, Planning Commission, Ministry of Planning, Bangladesh., 2012.
[21] HIES, Household Income and Expenditure Survey, Dhaka: Bangladesh Bureau of Statistics. Statistics Division, Ministry of Planning, 2016.

[22] A. R. Sunny, G. S. Ahamed, M. H. Mithun, M. A. Islam, B. Das and A. Rahman, "Livelihood Status of The Hilsa (Tenualosa ilisha) Fishers: The Case Of Coastal Fishing Community of The Padma River," Bangladesh Journal of Coastal Zone Management, vol. 22, no. 2, p. 469, 2019.

[23] R. C. Bhujel, "Small-scale aquaculture: Global and national perspectives," in Proceedings of the Symposium on 'Small-scale Aquaculture for Increasing Resilience of Rural Livelihoods in Nepal, Kathmandu, Nepal, 2009.

[24] A. Nesar, "The sustainable livelihoods approach to the development of fish farming in rural Bangladesh," Journal of International Farm Management, vol. 4, no. 4, pp. 1-18, 2009.

[25] Z. Ahmed, A. Sarker, M. Z. Rahman, B. Lei and M. Z. N. Mukta, "Fisheries extension in Bangladesh and local extension agent for fisheries: A micro level assessment of farmers' Attitude," International Journal of Fisheries and Aquatic Studies, vol. 6, pp. 92103, 2018.

[26] M. F. Hasan, "Factors affecting fish-farmers' attitude towards community managed fisheries in Dinajpur district," Journal of Innovation and Development Strategy, vol. 10, no. 1, pp. 40-46, 2016.

[27] M. Aziz and M. Hossain, "Fisheries in Trans-Himalayan region: prospects for fish culture in Hill Districts of Bangladesh," in Cold Water Fisheries in the Trans-Himalayan Countries., A. T. Petr and D. B. Swar, Eds., 2002.

[28] M. K. Ghosh, S. S. Hasan, M. E. Haque and M. J. Uddin, "Knowledge of farmers to sustainable agriculture practices: A case study in Southwestern region of Bangladesh," Scholars Journal of Agriculture and Veterinary Sciences, 2020.

[29] S. S. Hasan, X. Deng, Z. Li and D. Chen, "Projections of future land use in Bangladesh under the background of baseline, ecological protection and economic development.," Sustainability, vol. 9, no. 4, p. 505, 2017.

[30] M. K. Ghosh, S. S. Hasan, R. Fariha, M. O. Bari and M. A. Parvin, "Women Empowerment through Agriculture in Chapainawabganj, Bangladesh," European Journal of Agriculture and Food Sciences, vol. 3, no. 1, pp. 153-160, 2021.

[31] S. S. Hasan, M. E. Haque, I. Z. Suchi and A. Hossain, "Assessment of Diploma agricultural students' attitude towards educational sustainability: A study of selected agricultural training institutes of Bangladesh.," Journal of Education, Society and Behavioural Science, vol. 25, no. 2, pp. 1-12, 2018. 